DOI 10.15290/cnisk.2021.01.10.07

\title{
AGNIESZKA ZANIEWSKA
}

https://orcid.org/0000-0003-2713-7958

Uniwersytet w Białymstoku

\section{"Nasza Praca” - miesięcznik „wytycznych" do działań i praktyk Ligi Kobiet ${ }^{1}$}

\begin{abstract}
Streszczenie
Artykuł stanowi analize pisma „Nasza Praca”, wydawanego przez Zarzą Główny Ligi Kobiet jako wewnętrzny instruktaż do działania organizacji kobiecej w terenie. W latach 1947-1980 pismo wydawane było $\mathrm{w}$ formie biuletynu, którego treści przeznaczone były wyłącznie do analizy przez członkinie organizacji we wszystkich oddziałach na terenie Polski Ludowej. Natomiast od 1981 r. wraz z przełomem w kraju i w samej Lidze Kobiet „Nasza Praca” stała się ogólnodostępnym miesięcznikiem skierowanym do wszystkich Polek, w tym do niezrzeszonych w Lidze Kobiet. Poniższy artykuł koncentruje się wokół wytycznych Zarządu Głównego Ligi Kobiet dla działaczek terenowych na początku lat 80. ubiegłego wieku.

Słowa kluczowe: Liga Kobiet, „Nasza Praca”, organizacja kobieca, system komunistyczny

\footnotetext{
$1 \quad$ Artykuł przygotowany w ramach realizacji projektu badawczego Narodowego Centrum Nauki pt. „Liga Kobiet w terenie. Działalność organizacji i realia jej funkcjonowania na szczeblu regionalnym i lokalnym w rzeczywistości Polski Ludowej (1945-1989)", nr 2017/25/B/ HS3/02015.
} 


\title{
„NASZA PRACA" - A MONTHLY MAGAZINE OF “GUIDELINES" FOR THE ACTIVITIES AND PRACTICES OF THE WOMEN'S LEAGUE
}

\begin{abstract}
The article is an analysis of the "Nasza Praca" magazine published by the Main Board of the League of Women as an internal instruction of women's organizations in this field. In the years 1947-1981, the journal was published in the form of a bulletin, the content of which was intended solely for analysis by members of the organization in all branches of the Polish People's Republic. On the other hand, since 1981, with the breakthrough in the country and the League of Women itself, "Nasza Praca" became an open monthly addressed to all Polish women, including those who are not members of the Women's League. The following article focuses on the guidelines of the Main Board of the Women's League for field activists from the early 1980s.
\end{abstract}

Keywords: Women's League, "Nasza Praca", women's organization, communist system

\section{Wprowadzenie}

W sierpniu 1945 r. pod nazwa Społeczno-Obywatelska Liga Kobiet $^{2}$ utworzona została organizacja kobieca majaca na celu m.in. szeroko rozumiana obronę praw i interesów kobiet, zrzeszenie mas kobiecych oraz prowadzenie wśród nich pracy propagandowej (ideowo-wychowawczej) zgodnej $z$ linia $\mathrm{PPR}^{3}$. Ta dwutorowa działalność na rzecz kobiet i partii prowadzona była przez cały okres istnienia Polski Ludowej4. W poczatkowym czasie rozwoju organizacji, tj. do 1966 r., obszarem działalności Ligi Kobiet było całe terytorium Rzeczypospolitej, tj. w mieście i na wsi oraz we wszystkich

\footnotetext{
2 Organizacja pod nazwą Społeczno-Obywatelska Liga Kobiet (SOLK) działała w latach 1945-1949. We wrześniu 1949 r. zmieniła nazwę na Liga Kobiet (LK), a od 1982 r. funkcjonuje jako Liga Kobiet Polskich (LKP).

3 AAN, Ministerstwo Pracy i Opieki Społecznej (dalej: MPiOS), sygn. 300, Statut SOLK z 1945 r., k. 104.

4 Halina Sekuła-Kwaśniewicz, „Meandry ruchu kobiecego w czasach PRL”, Annales Universitatis Pedagogicae Cracoviensis. Studia Politologica, nr X, 2013, 66; Agnieszka Chłosta -Sikorska, „Boginie PRL - nowe role kobiety w społeczeństwie socjalistycznym”, w: Bożena Popiołek, Agnieszka Chłosta-Sikorska, Marcin Gadocha (red.), Kobieta i mężczyzna jedna przestrzeń - dwa światy, (Warszawa: Wydawnictwo DiG, 2015), 617; Maria Bauchrowicz-Tocka, „Ewolucja celów Ligi Kobiet w latach 1945-1989 w świetle jej statutów”, Czasopismo Naukowe Instytutu Studiów Kobiecych, nr 1(8), 2020, 176-191.
} 
zakładach pracy ${ }^{5}$. Jednak decyzją Komitetu Centralnego PZPR od czerwca 1966 r. Liga Kobiet miała prowadzić działalność jedynie na terenie miast i osiedli miejskich oraz wyłącznie w miejscu zamieszkania kobiet $^{6}$. Organem nadzorujaccym wszystkie kobiety zrzeszone w Lidze Kobiet, związkach zawodowych, kółkach rolniczych i spółdzielczych od 1966 r. stała się Krajowa Rada Kobiet Polskich powołana przez Ogólnopolski Komitet Frontu Jedności Narodu ${ }^{7}$. Powrót Ligi Kobiet do zakładów pracy nastapił w 1981 r., jednak już podczas VI Plenum KC PZPR (październik 1980 r.) przewodnicząca Zarządu Głównego Ligi Kobiet Eugenia Kempara zwróciła uwagę, iż należy pozwolić kobietom tworzyć oddziały Ligi Kobiet w zakładach pracy, bowiem „komisja to nie organizacja, kobiety nie miały się $\mathrm{z}$ kim identyfikować, nie miały programu politycznego ani wzajemnych więzi”. Swój referat zakończyła słowami: „Praca masowych organizacji społecznych to jest też jedna $z$ dróg dialogu partii ze społeczeństwem - to jedna $z$ dróg odzyskiwania wiarygodności jej programu" . I to właśnie był jeden $z$ głównych celów organizacji na początku lat 80. - odzyskanie wiarygodności organizacji oraz wiarygodności partii rządzącej, tj. PZPR ${ }^{10}$.

Periodyk stanowiący podstawę poniższych rozważań ukazywał się dość systematycznie od marca 1947 r. do końca 1989 r. ${ }^{11}$ W początkowym założeniu periodyk miał stanowić wewnętrzny

\footnotetext{
5 Istniały również zagraniczne koła Ligi Kobiet, np. w Sztokholmie i Bernie. Zob. Adam Miodowski, „Rozwój dolnośląskich i zachodniopomorskich struktur Społeczno-Obywatelskiej Ligi Kobiet w latach 1947-1949 w świetle publikacji "Naszej Pracy"”, w: Małgorzata Dajnowicz, Adam Miodowski (red.), Polityka i politycy w prasie XX i XXI wieku. Polityka w prasie kobiecej, (Białystok: Wydawnictwo Uniwersytetu w Białymstoku, 2019), 174.

6 Weronika Jackowska, „Z 35-letniej historii Ligi Kobiet”, Nasza Praca, nr 2, 1980, 25-26.

7 Ibidem, 14-27.

8 Eugenia Kempara, „VI Plenum KC PZPR”, Nasza Praca, nr 6, 1980, 9.

9 Ibidem, 10.

10 Emilia Świętochowska, „Sytuacja społeczno-zawodowa kobiet w ostatniej dekadzie PRL na przykładzie województwa białostockiego", w: Ewa Chabros, Agnieszka Klarman (red.), Kobiety na zakrecie 1933-1989, (Wrocław: IPN, 2014), 301-302; Anna Marcinkiewicz-Kaczmarczyk, „Rola Ligi Kobiet w popularyzowaniu polityki władz "Polski Ludowej»”, w: Dorota Litwin-Lewandowska, Krzysztof Bałękowski (red.), „Polska Ludowa” 1944-1989 - wybrane problemy historii politycznej $i$ społecznej, (Lublin: Wydawnictwo Naukowe Tygiel, 2016), 297-300.

11 Według ustaleń Adama Miodowskiego pierwszy numer „Naszej Pracy” przygotowywany był na przełomie 1946/1947 r. Więcej na ten temat zob. Adam Miodowski, „Działalność zagranicznych ruchów kobiecych w świetle publikacji "Naszej Pracy" - organu prasowego Społeczno-Obywatelskiej Ligi Kobiet (1947-1949)”, Czasopismo Naukowe Instytutu Studiów Kobiecych, nr 1(8), 2020, 141-142; Małgorzata Dajnowicz, „Działalność Społeczno-Obywatelskiej Ligi Kobiet w świetle "Naszej Pracy» (1947-1949), w: Małgorzata Dajnowicz, Adam
} 
biuletyn Społeczno-Obywatelskiej Ligi Kobiet. Jednak jego ściśle instruktażowy charakter $z$ biegiem lat podlegał przeobrażeniom i w 1981 r. „Nasza Praca” stała się ogólnodostępnym miesięcznikiem Ligi Kobiet. Przekształcenie pisma Ligi Kobiet było efektem kryzysowej sytuacji w kraju ${ }^{12}$. Od tego okresu miesięcznik „Nasza Praca” oprócz wiadomości o działaniach podejmowanych przez terenowe oddziały Ligi Kobiet zawierał informacje o charakterze ogólnym, które miały zainteresować kobiety niezrzeszone w Lidze Kobiet. Pojawiły się nowe działy, m.in.: $Z$ życia rodziny, Kobieta $w$ świecie, Kultura i oświata, Poznajemy prawo, Komitet Gospodarstwa Domowego radzi. Od 1982 r. jeden numer pisma co roku ukazywał się z podtytułem Poradnik metodyczny, w którym wzorem początkowych numerów biuletynu publikowano wyłącznie cele i zasady działania organizacji w terenie. Główne tematy poruszane na łamach miesięcznika w latach 80 . dotyczyły wychowania spoleczeństwa zgodnie $z$ oczekiwaniami partii rządzacej, poradnictwa prawno-społecznego, promowania rozbrojenia i pokoju na świecie oraz odzyskania utraconego przez Ligę Kobiet znaczenia wśród społeczeństwa polskiego ${ }^{13}$.

Nakład pisma w omawianym okresie wahał się w granicach 12-16 tys. egzemplarzy. W latach 80 . miesięcznik wydawany był przez RSW „Prasa-Ksiażka-Ruch”, a kolegium redakcyjne na poczatku lat 80. tworzyły kolejno: Eugenia Kempara - przewodniczaca i członkinie: Henryka Dęga, Teresa Elmerych, Barbara Gołąbek,

Miodowski (red.), Polityka i politycy $w$ prasie XIX $i$ XX wieku, (Białystok: Wydawnictwo Humanica, 2016), 295-307.

12 „Od Redakcji”, Nasza Praca, nr 1, 1981, 1. Zmiana nazwy organizacji została uchwalona podczas VIII Nadzwyczajnego Zjazdu Ligi Kobiet odbywającego się 28-29.11.1981 r. Maria Bauchrowicz-Tocka, „Działalność Ligi Kobiet Polskich w okręgach katowickim i krakowskim w świetle publikacji "Naszej Pracy“ (1982-1989)”, w: Małgorzata Dajnowicz, Adam Miodowski (red.), Ruchy kobiece na ziemiach polskich w XIX i XX wieku. Stan badań i perspektywy, (Białystok: Wydawnictwo Uniwersytetu w Białymstoku, 2020), 322; Agnieszka Drozdowska, „Działalność Ligi Kobiet w północno-wschodnich terenach Polski Ludowej w latach 19751989 w świetle "Naszej Pracy", Niepodległość i Pamięć, R. XXVI, nr 2(66), 2019, 190-191.

13 Danuta Markowska, „O wychowaniu dla przyszłości”, Nasza Praca, nr 3, 1980, 64-71; Irena Hamerska, „Cel - dalsza edukacja kobiet”, Nasza Praca, nr 3, 1980, 31-35; Eugenia Kempara, „Przeciwko faszyzmowi - za pokojem i rozbrojeniem”, Nasza Praca, nr 4, 1980, 3-6; Maria Regent-Lechowicz, „Wychowanie dla pokoju”, Nasza Praca, nr 4, 1980, 7-14; Melania Mroczek-Szymańska, „Kobiety polskie w zwycięstwie nad faszyzmem i w walce o pokój”, Nasza Praca, nr 4, 1980, 15-26; Agnieszka Drozdowska, „Działalność Ligi Kobiet w północno-wschodnich terenach Polski Ludowej”, 186-187; eadem, „Liderki Ligi Kobiet Polskich wobec wyborów w latach 80. (w świetle "Naszej Pracy")", Czasopismo Naukowe Instytutu Studiów Kobiecych, nr 1(8), 2020, 196. 
Irena Hamerska, Weronika Jackowska, Alicja Zdybel, a sekretarzem redakcji w 1980 r. była Jolanta Kroner ${ }^{14}$. Skład kolegium redakcyjnego zmienił się już w 7 numerze $z 1981 \mathrm{r}^{15}$

Pierwsze strony periodyku poświęcone były najczęściej bieżącym wydarzeniom politycznym, tj. zjazdy PZPR, zjazdy Ligi Kobiet czy Krajowej Rady Kobiet. Publikowano wówczas uchwały Zarządu Głównego Ligi Kobiet i wytyczne działania Ligi Kobiet w terenie, referaty wygłoszone podczas Plenum, a także różnego rodzaju listy i gratulacje dla Ligi Kobiet za jej zaangażowanie na rzecz poprawy sytuacji kobiet i dzieci ${ }^{16}$. Na łamach biuletynu publikowano ponadto podziękowania składane Lidze przez różnych przedstawicieli władz państwowych oraz komitetów społecznych, np. za zaangażowanie Ligi w budowę Pomnika - Szpitala Centrum Zdrowia Dziecka poprzez organizowanie zbiórek pieniędzy na ten $\operatorname{cel}^{17}$. W latach 80 . coraz większa uwagę zwracano również na potrzeby osób starszych, które od października 1975 r. mogły uczestniczyć w zajęciach prowadzonych na Uniwersytecie III Wieku ${ }^{18}$. Kolejne numery miesięcznika miały słabiej rozbudowana gamę tematyczna. Koncentrowano się zazwyczaj na jednym lub dwóch zagadnieniach $z$ zakresu poradnictwa prawno-społecznego oraz zmian politycznych w kraju. $\mathrm{Na}$ ostatnich stronach pisma pojawiała się najczęściej kronika wydarzeń, w której w bardzo ogólny sposób sygnalizowano zdarzenia $z$ ubiegłych miesięcy. Ważnym do badań nad działalnościa Ligi Kobiet w terenie jest dział $Z$ działalności kół $i$ zarzadów, w którym publikowano wiadomości nadsyłane $z$ zarządów wojewódzkich.

Na łamach periodyku ukazywały się materiały pomocowe do planowania działalności organizacji w terenie na nadchodzący rok, które uwzględniać miały najważniejsze święta i rocznice państwo$w^{19}$. Ponadto wyjaśniano adresatkom periodyku zasady tworzenia

\footnotetext{
Nasza Praca, nr 1, 1980, 2.

Nasza Praca, nr 7, 1981.

„Uchwała ZG LK w sprawie dalszego rozwijania działalności na rzecz pomocy rodzinie”, Nasza Praca, nr 1, 1980, 25-27; „Uchwała ZG LK w sprawie kampanii sprawozdawczo-wyborczej w kołach LK, ORW i KRM”, Nasza Praca, nr 1, 1980, 28-29; „Plenum Krajowej Rady Kobiet Polskich przy Ogólnopolskim Komitecie FJN”, Nasza Praca, nr 3, 1980, 5-7; „III Plenum Zarządu Głównego Ligi Kobiet”, Nasza Praca, nr 3, 1980, 8-23.

17 Janusz Wieczorek, „Podziękowanie dla Ligi Kobiet”, Nasza Praca, nr 1, 1980, 3-4.

18 Barbara Gołąbek, „Seniorzy wśród nas”, Nasza Praca, nr 5, 1980, 61-65; Halina Szwarc, „5 lat działalności Uniwersytetu III Wieku”, Nasza Praca, nr 5, 1980, 66-70.

19 Teresa Elmerych, „Kalendarium rocznic i obchodów w 1981 r. Pomoc do planowania pracy w ogniwach LK", Nasza Praca, nr 5, 1980, 31-34.
} 
programów organizacji i aspekty, jakie należy przy tym uwzględnić, tj. np. sprecyzowanie działań okresowych i długofalowych, liczbę aktywu i tematy spotkań poświęcone problemom kobiet ${ }^{20}$. Wskazywano również zasady umożliwiające sprawne kierowanie oddziałem organizacji: np. „efektywne kierowanie ludźmi winno zakładać duży zakres samodzielności podwładnych. ... konieczność posiadania przez kierowników "pewnej dozy skromności i połączonego $z$ ta skromnością przeświadczenia, że i poza kierownikami sa jeszcze ludzie na świecie, którzy chociaż nie piastują wysokich stanowisk, potrafią to i owo należycie wykonać" "21. Wśród instrukcji prezentowanych na łamach pisma były również wytyczne prowadzenia działalności kulturalno-oświatowej ${ }^{22}$.

\section{Rozwinięcie}

Niewatpliwie kierunki działalności Ligi Kobiet zależne były od sytuacji społeczno-gospodarczej kraju i wytycznych władzy komunistycznej. Wśród zadań Ligi Kobiet wyznaczonych przez VIII Zjazd PZPR (luty 1980 r.) było „pogłębianie więzi z ogółem mieszkańców” osiedli miast i

wychowanie młodego pokolenia przez pracę, dla wzorowego wypełniania powinności pracownika i obywatela. Poczesne miejsce w systemie edukacji zajmuje rodzina i środowisko, a w nim kobieta: matka, obywatelka, ofiarna działaczka społeczna, dobry pracownik ${ }^{23}$.

Kolejność ról pełnionych przez kobiety wskazywała oczekiwania władzy wobec kobiet. Oczekiwania, które spełnić miała Liga Kobiet - przestawić system wartości Polek, które przede wszystkim miały być matkami i angażować się w działalność społeczna, a dopiero na końcu, jeśli zachodziła taka konieczność, miały zostać

\footnotetext{
20 Weronika Jackowska, „Programowanie działań organizacji”, Nasza Praca, nr 6, 1980, 11-29.

21 Eugenia Kempara, „Zasady sprawnego kierowania”, Nasza Praca, nr 6, 1980, 31.

22 Irena Hamerska, „Jak prowadzić działalność kulturalno-oświatową w Lidze Kobiet”, $\mathrm{Na}$ sza Praca, nr 6, 1980, 35-66.

23 Weronika Jackowska, „Nowy etap działalności samorządu mieszkańców miast”, Nasza Praca, nr 3, 1980, 24-30; Irena Hamerska, "Cel - dalsza edukacja kobiet”, Nasza Praca, nr 3, 1980, 31; Danuta Markowska, „O wychowaniu dla przyszłości”, Nasza Praca, nr 3, 1980, 64-71.
} 
dobrymi pracownicami. Ponadto podczas VIII Zjazdu PZPR wskazano, że celem Ligi Kobiet winno być „stwarzanie warunków do zwiększenia uczestnictwa ludzi pracy i ich rodzin w turystyce, rekreacji i różnych formach czynnego wypoczynku"24. Organizowanie urlopów i czasu wolnego obywateli miało pomóc w wychowaniu ich zgodnie $\mathrm{z}$ ideologia komunistyczna i zaangażowaniu w działalność oczekiwaną przez partię $e^{25}$.

Ważnym aspektem działalności Ligi Kobiet było prowadzenie poradni prawno-społecznych ${ }^{26}$. Na łamach „Naszej Pracy” pojawiały się bardzo często wskazówki dotyczace prowadzenia poradni i udzielania porad prawnych. Dla przykładu: Janina Sławecka sędzia Sądu Wojewódzkiego w Warszawie - opisała stan prawny z zakresu prawa spadkowego. Wyjaśniała w swoim artykule podstawowe pojęcia prawne, takie m.in. jak: spadkobierca, spadkodawca czy dziedziczenie ustawowe i testamentowe, oraz zaapelowała o konieczność przybliżania zagadnień prawnych kobietom w całej Polsce najlepiej przez wykorzystanie kwalifikacji członkiń Sekcji Kobiet Prawników utworzonej przy LK 30 września 1959 r. ${ }^{27}$ Sekcja ta w 1980 r. liczyła 1057 aktywistek działajacych w 39 oddziałach terenowych Ligi $^{28}$. Jej zadaniem było nie tylko przybliżenie kobietom zagadnień prawnych ${ }^{29}$, ale także opiniowanie projektów ustaw $\mathrm{w}$ celu doskonalenia systemu prawnego ${ }^{30}$. Jak stwierdziła w wywiadzie przewodniczaca Sekcji Kobiet Prawników przy LK - Janina Polony, będąca jednocześnie sędzią Sądu Najwyższego, celem Sekcji było „tworzenie takiego prawa, które gwarantowałoby trwałość

\footnotetext{
24 Teresa Elmerych, „Rekreacja i wypoczynek - przedmiotem dyskusji w resortach i organizacjach społecznych”, Nasza Praca, nr 4, 1980, 27.

25 Adam Kurzynowski, „Na urlop czy do pracy?”, Nasza Praca, nr 9, 1981, 22-27.

26 Więcej na temat poradni prawno-społecznych zob. Małgorzata Dajnowicz, „Liga Kobiet w terenie. Kierunki działalności organizacji na przykładzie struktur białostockich w latach 1966-1981”, Niepodległość i Pamięć, nr 2(62), 2018, 167, 170; Agnieszka Drozdowska, „Działalność Ligi Kobiet w północno-wschodniej części Polski Ludowej, 194; eadem, „O działalności Ligi Kobiet w okręgu białostockim (w świetle "Naszej Pracy»)", w: Małgorzata Dajnowicz, Adam Miodowski (red.), Polityka i politycy w prasie XX i XXI wieku, 201-203.

27 Janina Sławecka, „Podstawowe zagadnienia prawa spadkowego”, Nasza Praca, nr 1, 1980, 51-56; Zofia Groyecka, „Sekcja kobiet prawników przy LK”, Nasza Praca, nr 2, 1980, 60.

28 Zofia Groyecka, „Sekcja kobiet prawników”, 60.

29 Wanda Stojanowska, „Pochodzenie dziecka. Cz. I. Sądowne ustalenie ojcostwa”, Nasza Praca, nr 4, 1980, 58-66.

30 Barbara Błachowska, „Nowelizacja Kodeksu pracy. Uwagi do projektu”, Nasza Praca, nr 6, $1981,36-43$
} 
rodziny, wysuwało na pierwszy plan dobro dziecka i zrównywałoby małżonków we wszystkich uprawnieniach" ${ }^{31}$.

Istotne było również prowadzenie poradnictwa rodzinnego ${ }^{32}$. W latach 80. zwracano uwage, że nie tylko matka wychowuje dzieci, ale także ojciec winien brać w tym czynny udział. Refleksyjnie stwierdzono, że: „o roli kobiety-matki w życiu rodziny wiemy wiele. O ojcu mówi się dotąd zbyt mało”33. Liga na łamach „Naszej Pracy” prezentowała dotychczasowy dorobek organizacji na rzecz zmiany świadomości kobiet, które winny oczekiwać partnerskiego traktowania $\mathrm{w}$ swoich związkach, dążyć do zaangażowania mężczyzn w zajęcia domowe i wychowywanie dzieci. Podkreślano, że „dla harmonijnego rozwoju psychicznego i uczuciowego dziecka potrzebna jest aktywna obecność w jego życiu obojga rodziców. Roli ojca $\mathrm{w}$ wychowaniu nie da się przecenić" ${ }^{34}$. Potwierdzać to miały fragmenty listów napisanych przez dzieci i młodzież na konkurs „Mój ojciec”, zorganizowany przez Zarząd Wojewódzki Ligi Kobiet w Bydgoszczy ${ }^{35}$.

Jednym $z$ najbardziej popularnych konkursów organizowanych przez Zarząd Główny Ligi Kobiet był konkurs „Rodzina w klubie"36. Konkurs po raz pierwszy został zorganizowany w $1968 \mathrm{r}^{37}$, a ostatni (XI) etap zorganizowano w 1980 r. Konkurs miał na celu aktywizację różnych organizacji społeczno-kulturalno-oświatowych na rzecz

kształtowania postaw społeczno-politycznych i wychowawczych rodziców ... poznaniu historii i ... osiagnięć naszego kraju i jego regionów ... upowszechnianie prawidłowych zasad życia rodzinnego i społecznego ... X etapowi „Rodzina w klubie” towarzyszył konkurs czytelniczy „Rodzina i prawo” mający na celu popularyzacje podstawowych norm prawnych dotyczacych statusu kobiety, rodziny i dziecka, wyrabianie szacunku dla prawa oraz uczenie

\footnotetext{
31 Joanna Horodecka, „W środku życia. Rozmowa z sędzią Sądu Najwyższego Janiną Polony, przewodnicząca Sekcji Kobiet Prawników przy Lidze Kobiet”, Nasza Praca, nr 2, 1980, 65.

32 Agnieszka Makowska, „Poradnictwo społeczne i rodzinne LK”, Nasza Praca, nr 3, 1980, 52-57.

33 Maria Krawczyk, „Portret Ojca”, Nasza Praca, nr 1, 1980, 69.

34 Ibidem.

35 Ibidem, 69-78.

36 Irena Hamerska, „Konkurs "Rodzina w klubie» po dziesięciu etapach”, Nasza Praca, nr 1, 1980, 43-50.

37 Eadem, „35 lat działalności ideowo-wychowawczej i kulturalno-oświatowej”, Nasza Praca, nr 2, 1980, 57.
} 
właściwej interpretacji przepisów prawnych i praktycznego wykorzystania nabytej w tym zakresie wiedzy ${ }^{38}$.

Akcja „Rodzina w klubie” przybierała różne formy upowszechniania wspomnianych celów wśród społeczeństwa. Najbardziej popularne były wieczory filmowe, wystawy i spektakle, które miały wpłynąć na właściwe, zgodne $z$ oczekiwaniami władzy komunistycznej, postawy obywateli ${ }^{39}$. W $1981 \mathrm{r}$. podjęto decyzję o „niewprowadzaniu do programu działania ... konkursu "Rodzina w klubie", konkursów czytelniczych i Klubu Ksiażki dla rodziny "Ewa" $z$ uwagi na trudności wydawnicze i ograniczony przydział książek"40 oraz trudną i złożoną sytuację społeczno-gospodarczą w kraju. Natomiast kontynuowane miały być m.in. szkoły obywatelskiego wychowania kobiet ${ }^{41}$, obchody rocznic i swiąt państwowych, prelekcje, konferencje i seminaria oraz poradnictwo społeczno-prawne, rodzinno-wychowawcze i z zakresu ekonomiki gospodarstwa domowego. Ponadto we wszystkich oddziałach Ligi Kobiet w terenie należało wprowadzić „cykl imprez kulturalno-rozrywkowych pod wspólnym hasłem "Życie codzienne rodzin w krajach socjalistycznych""42.

Wśród sekcji działających przy Lidze Kobiet była również Sekcja Budownictwa. Według informacji zawartych $\mathrm{w}$ materiale źródłowym była to jedna $z$ najbardziej znaczacych grup, która powołana została w 1964 r. Skupiała ona kobiety

bezpośrednio zwiazane $z$ budownictwem mieszkaniowym. Sa wśród nich inżynierowie-architekci różnych specjalności: urbaniści, projektanci, plastycy, architekci wnętrz, technicy. ... podjęła zadanie upowszechniania wśród kobiet kultury użytkowania mieszkań, prezentowania ich opinii i wniosków na temat budownictwa mieszkaniowego i funkcjonalnego rozwiazania budownictwa towarzyszaceego w osiedlach ${ }^{43}$.

Estetyka była ważnym zagadnieniem rozpowszechnianym wśród czytelniczek pisma.

\footnotetext{
38 Eadem, „Konkurs "Rodzina w klubie» po dziesięciu etapach, 44-47.

39 Ibidem, 48.

40 Teresa Elmerych, „Kierunki działalności programowej w 1981 r.”, Nasza Praca, nr 5, 1980, 15.

41 Wanda Komar, „Szkoły wychowania obywatelskiego w LK. Cele, zadania, program, perspektywy", Nasza Praca, nr 5, 1980, 35-38.

42 Teresa Elmerych, „Kierunki działalności programowej”, 16-17.

43 Krystyna Zalewska, „Sekcja Budownictwa LK”, Nasza Praca, nr 2, 1980, 89.
} 
Ponadto numery $z$ lat 80. pozwalaja prześledzić rozwój współpracy Ligi Kobiet $z$ innymi organizacjami dążącymi do poprawy sytuacji kobiet i ich rodzin. Wśród wieloletnich sojuszników wskazywano m.in. związki zawodowe, Towarzystwo Przyjaźni Polsko-Radzieckiej, Polski Czerwony Krzyż czy Zwiąek Bojowników o Wolność i Demokrację, Związek Harcerstwa Polskiego oraz Ministerstwo Kultury i Sztuki będące patronem konkursów czytelniczych i „Rodzina w klubie”44. Rocznie Liga Kobiet miała organizować ok. 13 tys. spotkań/prelekcji na tematy społeczno-polityczne, gospodarcze i oświaty zdrowotnej, w których udział brało ok. 350 tys. osób ${ }^{45}$.

Wśród działów tematycznych „Naszej Pracy” istniał też dział poświęcony międzynarodowej działalności i współpracy Ligi Kobiet ${ }^{46}$. Od początku ukazywania się biuletynu dużą uwage koncentrowano na aktywności Ligi Kobiet w ramach powołanej w 1945 r. Światowej Demokratycznej Federacji Kobiet, której pierwsza wiceprzewodnicząca została wiceprzewodnicząca SOLK - Eugenia Pragierowa ${ }^{47}$. Często pojawiały się informacje na temat wyjazdów zagranicznych i przyjmowania delegacji organizacji kobiecych $z$ innych państw. Najczęściej były to delegatki $z$ sąsiednich krajów socjalistycznych ${ }^{48}$. Przykładem jest delegacja kobiet syryjskich, która przybyła do Warszawy na zaproszenie Krajowej Rady Kobiet Polskich. Przedstawicielki Zwiazku Kobiet Syryjskich odwiedziły wówczas ośrodki prowadzone przez Ligę Kobiet na Białostocczyźnie (Sokółka) i w województwie łomżyńskim. Zaprezentowano im dotychczasowe osiagnięcia i zasady działania Ligi Kobiet w terenie. Natomiast kobiety syryjskie przedstawiły sytuacje kobiet w Syrii i trudności, $z$ jakimi spotyka się ich organizacja kobieca ${ }^{49}$. Niewątpliwie przyjazd delegatek syryjskich na Białostocczyznę sta-

\footnotetext{
44 Teresa Elmerych, „Sojusznicy naszej działalności”, Nasza Praca, nr 2, 1980, 28-35.

45 Irena Hamerska, „35 lat działalności ideowo-wychowawczej”, 58.

46 Eugenia Kempara, „Światowa Konferencja Dekady Kobiet w Kopenhadze”, Nasza Praca, nr 5, 1980, 89-92. Na temat międzynarodowej działalności Ligi Kobiet w pierwszych latach jej rozwoju zob. Adam Miodowski, „Działalność zagranicznych ruchów kobiecych”, 140-157. 47 Weronika Jackowska, „Z 35-letniej historii Ligi Kobiet”, 19.

48 „Wizyta delegacji radzieckiej”, Nasza Praca, 1981, nr 8, 43-44.

49 Przypomniano wówczas, że w 1979 r., ogłoszonym Międzynarodowym Rokiem Dziecka, Liga Kobiet wystosowała Apel w sprawie solidarności z dziećmi z ośrodka sierot wojennych w Damaszku. „Apel w sprawie solidarności $z$ dziećmi $z$ ośrodka sierot wojennych w Damaszku”, Nasza Praca, nr 1-2, 1979, 12-13; Maria Laskowska, „Delegacja kobiet syryjskich w Polsce", Nasza Praca, nr 1, 1980, 87-90.
} 
nowił wyróżnienie dla działalności tutejszych działaczek, bowiem jak wynika $z$ artykułu, Sokółka i Łomża były jedynymi miejscowościami (oprócz Warszawy), gdzie udała się delegacja Związku Kobiet Syryjskich ${ }^{50}$.

Informowano również, że przedstawicielka Zarząu Głównego Ligi Kobiet i Sekcji Kobiet Prawników, Eugenia Berutowicz, uczestniczyła w międzynarodowym seminarium „Sytuacja kobiety - prawo i rzeczywistość", zorganizowanym w Cambridge przez Międzynarodowe Zrzeszenie Prawników Demokratów. Informacja na ten temat pojawiła się w pierwszym numerze $z 1980$ r., w dziale zatytulowanym Kronika wydarzeñ ${ }^{51}$. W dziale tym w sposób bardzo usystematyzowany pojawiały się krótkie wiadomości dotyczące aktywności Zarządu Głównego Ligi Kobiet oraz oddziałów wojewódzkich.

W piśmie w niewielkim stopniu odnoszono się do sytuacji społeczno-gospodarczej kraju. Sugerowano jedynie istnienie trudności zaopatrzeniowych, które dałoby się rozwiązać dzięki jeszcze większej edukacji kobiet $\mathrm{z}$ zakresu racjonalnego prowadzenia gospodarstwa domowego. Liga Kobiet w lutym 1979 r. zyskała możliwość „oceny jakości wyrobów, usług, robót i obiektów budowlanych" 52 . W tym celu Komitet Gospodarstwa Domowego miał sprawdzać jakość towarów i usług pod względem zaspokajania potrzeb konsumentów oraz publikować wyniki tych badañ ${ }^{53}$.

$\mathrm{Na} ł a m a c h$ pisma analizowano problem zatrudnienia kobiet, za sukces podajac podniesienie poziomu wykształcenia i aktywizację zawodowa kobiet w celu realizacji planu sześcioletniego. Brak jednak odniesienia się organizacji do masowych zwolnień, jakie nastapiły po zakończeniu realizacji planu ${ }^{54}$. Bardziej roszczeniowy charakter artykułów prezentuja numery z $1981 \mathrm{r}$. (okres kryzysów społecznych i gospodarczych). Liga Kobiet zauważała wówczas problem niedoceniania kobiet $\mathrm{w}$ zakładach pracy, nierówne płace za tę samą pracę i niewielką liczbę stanowisk kierow-

\footnotetext{
50 W latach 80. Zarząd Wojewódzki Ligi Kobiet jako jeden $z$ nielicznych gościł również delegacje kobiecych organizacji z Czechosłowacji, Koreańskiej Republiki Ludowo-Demokratycznej. Agnieszka Drozdowska, „Działalność Ligi Kobiet w północno-wschodniej części Polski Ludowej", 200.

51 „Kronika wydarzeñ”, Nasza Praca, nr 1, 1980, 91.

52 Anna Kędzierska, „Badania użytkowe prowadzone w KGD”, Nasza Praca, nr 2, 1980, 86.

53 Ibidem, 87.

54 Barbara Gołąbek, „Rola LK w aktywizacji zawodowej kobiet”, Nasza Praca, nr 3, 1980, 48-51.
} 
niczych zajmowanych przez kobiety ${ }^{55}$. Liga Kobiet starała się na nowo zjednoczyć kobiety pracujące w organizacji kobiecej poprzez pomoc $\mathrm{w}$ znalezieniu zatrudnienia i uświadamianiu ich prawnie i ekonomicznie ${ }^{56}$.

Od 1981 r. pojawiały się na łamach pisma dyskusje wywołane licznymi artykułami i listami kierowanymi do Ligi Kobiet na temat przydatności i zasadności istnienia Ligi Kobiet. Kobiety zarzucać miały niepraktyczność i słaba skuteczność Ligi Kobiet. Wśród tematów, jakie się pojawiały, była m.in. poruszana kwestia, dlaczego sprawami kobiet ma się zajmować wyłącznie organizacja kobieca, czy nie powinny one być dyskutowane razem z mężczyznami (Barbara Sidorczuk, „Razem czy osobno”, Kobieta i Życie, $\mathrm{nr} 49 / 80)^{57}$, niektórzy proponowali „rozwiązanie towarzystwa wzajemnej adoracji pod nazwą Liga Kobiet", a jeszcze inni sugerowali, że pomoc w rozwiązywaniu codziennych trudności otrzymuja przede wszystkim od komitetu, naczelnika czy rady zakładowej („Liga ... od dawna nie jest już pierwszą instancja, do której zwracaja się kobiety, lecz - ostatnia, gdy wszystkie już zawiodły"58). Negatywny wydźwięk dyskusji skłonił Zarząd Główny Ligi Kobiet do opublikowania artykułu pt. „Czy trzeba się wstydzić Ligi Kobiet?”59, w którym krytycznie odniesiono się do uwag zamieszczonych na łamach „Przyjaciółki” („Czy tylko babskie gadanie?”, nr 30 z lipca 1980 r.) i „Kobiety i Życia” o bierności Ligi w poprzednich latach. Szalę goryczy przelał "wywiad p. Anny Walentynowicz z gdańskiej "Solidarności": „”... Będę szczera - wstydzę się po prostu, że należałam do tej organizacji...", nr 5 z lutego 1981 roku)"60. Organizacja starała się wykazać swój dorobek na rzecz kobiety i rodziny oraz wytłumaczyć swoje nieistnienie w zakładach pracy. Ponadto w ramach ogólnej dostępności pisma na łamach „Naszej Pracy” pojawiały się również informacje na temat działalności „Solidarności”, jej zjazdów i kie-

\footnotetext{
55 „Socjalistyczne przemiany $z$ naszym udziałem. Referat przewodniczacej KRKP Eugenii Kempary", Nasza Praca, nr 2-3, 1981, 4-21.

56 Małgorzata Dajnowicz, "Zwierciadło" - platforma polityczna Ligi Kobiet w okresie PRL (1957-1961, 1982-1989)”, Rocznik Historii Prasy Polskiej, t. 20, z. 3(47), 2017, 71; eadem, „Liga Kobiet w terenie”, 176-178.

57 Halina Okoń, „Razem czy osobno”, Nasza Praca, nr 2-3, 1981, 60-62.

58 „Zachęcamy do dyskusji”, Nasza Praca, nr 2-3, 1981, 57-60.

59 Teresa Elmerych, „Czy trzeba się wstydzić Ligi Kobiet?”, Nasza Praca, nr 4, 1981, 2.

60 Ibidem.
} 
runków działań ${ }^{61}$. Miało to na celu ukazanie czytelniczkom istnienia wolności słowa w periodyku, ale także jedności z kobietami bez względu na ich przekonania polityczne.

Burzliwą dyskusję na łamach „Naszej Pracy” wywołała również zmiana nazwy organizacji na Ligę Kobiet Polskich. Członkinie Ligi Kobiet na przyspieszonym Zjeździe Ligi Kobiet wiosna 1982 r. prezentowały swoje stanowiska wobec powyższego problemu. Większość wypowiedzi była krytyczna wobec dotychczasowej działalności organizacji. Kobiety z gdańskich oddziałów Ligi Kobiet proponowały zmianę nazwy na Zwiazek Kobiet Polskich ${ }^{62}$. Natomiast reprezentantki województwa szczecińskiego podkreślały dorobek Ligi. Były to jednak nieliczne głosy. Mówiono, że

Musimy iść naprzód ... w obecnym kształcie organizacja nie może spełniać dobrze swoich zadań. ... Zostaniemy przy podwórkach, bo statut, mimo wprowadzonych ostatnio zmian, nie jest adekwatny do potrzeb ${ }^{63}$.

Postulaty programowe wygłoszone na Zjeździe dotyczyły bezwzględnego zachowania istnienia organizacji i bardziej efektywnego działania na rzecz równouprawnienia kobiet ${ }^{64}$. Założenia programowe z 1981 r. (po VIII Nadzwyczajnym Zjeździe LK) to:

Umacnianie pozycji kobiety w życiu społeczno-politycznym, w gospodarce narodowej ... udział organizacji $\mathrm{w}$ kształtowaniu polityki społecznej państwa na rzecz rodziny ... upowszechnianie w społeczeństwie modelu rodziny partnerskiej ... działania służące kształtowaniu osobowości i postaw kobiet ... pomoc społeczno-prawna i działalność opiekuńcza ... rozwijanie działań w zakładach pracy ... doskonalenie pracy organizacji $\mathrm{w}$ miejscu zamieszkania ... popularyzowanie organizacji i jej programu ... rozwijanie współpracy i wymiany doświadczeń z organizacjami kobiecymi innych krajów ${ }^{65}$.

\footnotetext{
61 „Materiały i dokumenty. Plenum Zarządu Głównego Ligi Kobiet”, Nasza Praca, nr 10, 1981,1 .

62 Małgorzata Dajnowicz, „"Zwierciadło" - platforma polityczna Ligi Kobiet”, 71; Barbara Nowak, Serving Women and the State: The League of Women in Communist Poland, Dissertation, (The Ohio State University 2004), 248, [online] [dostęp: 9.04.2021]. Dostępny w World Wide Web < https://etd.ohiolink.edu/apexprod/rws_etd/send_file/send?accession=osu 109 1553624\&disposition=inline $>$.

63 „Zjazd przyspieszony - wiosna '82”, Nasza Praca, nr 6, 1981, 15; „Liga Kobiet domaga się...", Nasza Praca, nr 6, 1981, 22-25.

64 „Zjazd przyspieszony - wiosna '82”, 11-19.

65 „Założenia programowe Ligi Kobiet”, Nasza Praca, nr 10, 1981, 16-19.
} 
Te kierunki działania w kolejnych latach nie podlegały większym przeobrażeniom ${ }^{66}$. Stanowiły one wyznaczniki aktywności, w jakich miały się realizować aktywistki Ligi Kobiet na rzecz pomocy kobietom. Powyższe założenia programowe ukierunkowały główny nurt dalszego rozwoju organizacji kobiecej oraz wskazywały możliwości realnej sprawczości organizacji, wcielania ich w życie przez oddziaływanie na społeczeństwo i władze państwowe (np. pomoc prawno-społeczna, wsparcie zatrudnienia kobiet czy opiniowanie projektów ustaw).

\section{Zakończenie}

Periodyk systematyzuje informacje na temat powstania, rozwoju i działalności Ligi Kobiet w czasie istnienia Polski Ludowej. Numery pisma $z$ lat 80 . bardzo często zawierają odniesienia do ubiegłych wydarzeń i doświadczeń organizacji. Powracającym motywem sa wspomnienia działaczek Ligi Kobiet ukazujące historię ich aktywności w szeregach Ligi. Publikowano je zwłaszcza w jubileuszowych numerach, np. $z$ okazji 35-lecia istnienia Ligi Kobiet ${ }^{67}$. W okresie badawczym koncentrowano uwagę na pomocy społeczno-prawnej organizowanej przez Ligę, walce o równouprawnienie kobiet, ale także pojawiła się krytyczna ocena jej działalności i skuteczności w osiaganiu celów. „Nasza Praca” ukazuje dzieje organizacji kobiecej, które odzwierciedlały sytuację społeczno-polityczno-gospodarczą kraju. Wydarzenia te pozwalaja zaobserwować zmianę sposobu wyrażania potrzeb kobiet i wzrost ich świadomości politycznej i roszczeń wobec władzy, ale także ciagłe poparcie Ligi Kobiet dla partii komunistycznej68.

Miesięcznik „Nasza Praca” w latach 80. ze względu na swój ogólnodostępny charakter $\mathrm{w}$ mniejszym niż dotychczas stopniu koncentrował się na udzielaniu wytycznych do działania oddziałów. W głównej mierze wskazówki dotyczyły konieczności podtrzymania dotychczasowej działalności w terenie i odbudowania zaufania Polek. Wytyczne wskazywały na potrzebę koncentrowania się na aktywności poradniczej i wychowawczej, która pozwoliłaby odbudować zaufanie do Ligi Kobiet oraz PZPR.

\footnotetext{
66 „Kierunki działania Ligi Kobiet Polskich w 1984 roku”, Nasza Praca, nr 2, 1984, 4-7.

67 Weronika Jackowska, „Z 35-letniej historii Ligi Kobiet”, 14-27.

68 Eugenia Kempara, "Nic o nas bez nas. Wystapienie na VII Plenum KC PZPR”, Nasza Praca, nr 1, 1981, 3-7.
} 


\section{Bibliografia}

\section{Źródla}

AAN, Ministerstwo Pracy i Opieki Społecznej, sygn. 300, Statut SOLK z 1945 r., k. 104.

„III Plenum Zarządu Głównego Ligi Kobiet”, Nasza Praca, nr 3, 1980, 8-23.

„Apel w sprawie solidarności $z$ dziećmi $z$ ośrodka sierot wojennych w Damaszku", Nasza Praca, nr 1-2, 1979, 12-13.

Błachowska, Barbara. „Nowelizacja Kodeksu pracy. Uwagi do projektu", Nasza Praca, nr 6, 1981, 36-43.

Elmerych, Teresa. „Czy trzeba się wstydzić Ligi Kobiet?”, Nasza Praca, nr 4, 1981, 2.

Elmerych, Teresa. „Kalendarium rocznic i obchodów w 1981 r. Pomoc do planowania pracy w ogniwach LK", Nasza Praca, nr 5, 1980, 31-34.

Elmerych, Teresa. „Kierunki działalności programowej w 1981 r.”, Nasza Praca, nr 5, 1980, 15-17.

Elmerych, Teresa. „Rekreacja i wypoczynek - przedmiotem dyskusji w resortach i organizacjach społecznych", Nasza Praca, nr 4, 1980, 27.

Elmerych, Teresa. „Sojusznicy naszej działalności”, Nasza Praca, nr 2, 1980, 28-35.

Eugenia, Kempara. „Nic o nas bez nas. Wystapienie na VII Plenum KC PZPR", Nasza Praca, nr 1, 1981, 3-7.

Gołąbek, Barbara. „Rola LK w aktywizacji zawodowej kobiet”, Nasza Praca, nr 3, 1980, 48-51.

Gołąbek, Barbara. „Seniorzy wśród nas”, Nasza Praca, nr 5, 1980, 61-65.

Groyecka, Zofia. „Sekcja kobiet prawników przy LK”, Nasza Praca, nr 2, 1980, 60.

Hamerska, Irena. „35 lat działalności ideowo-wychowawczej i kulturalno-oświatowej", Nasza Praca, nr 2, 1980, 57-58.

Hamerska, Irena. „Cel - dalsza edukacja kobiet”, Nasza Praca, nr 3, 1980, 31-35.

Hamerska, Irena. „Jak prowadzić działalność kulturalno-oświatowa w Lidze Kobiet", Nasza Praca, nr 6, 1980, 35-66.

Hamerska, Irena. „Konkurs "Rodzina w klubie" po dziesięciu etapach”, Nasza Praca, nr 1, 1980, 43-50. 
Hamerska, Irena. „35 lat działalności ideowo-wychowawczej i kulturalno-oświatowej”, Nasza Praca, nr 2, 1980, 57.

Horodecka, Joanna. „W środku życia. Rozmowa z sędzią Sądu Najwyższego Janina Polony, przewodniczaca Sekcji Kobiet Prawników przy Lidze Kobiet”, Nasza Praca, nr 2, 1980, 65.

Jackowska, Weronika. „Nowy etap działalności samorządu mieszkańców miast”, Nasza Praca, nr 3, 1980, 24-30.

Jackowska, Weronika. „Programowanie działań organizacji”, Nasza Praca, nr 6, 1980, 11-29.

Jackowska, Weronika. „Z 35-letniej historii Ligi Kobiet”, Nasza Praca, nr 2, 1980, 14-27.

Kempara, Eugenia. „VI Plenum KC PZPR”, Nasza Praca, nr 6, 1980, 9-10.

Kempara, Eugenia. „Przeciwko faszyzmowi - za pokojem i rozbrojeniem", Nasza Praca, nr 4, 1980, 3-6.

Kempara, Eugenia. „Światowa Konferencja Dekady Kobiet w Kopenhadze", Nasza Praca, nr 5, 1980, 89-92.

Kempara, Eugenia. „Zasady sprawnego kierowania”, Nasza Praca, nr 6, 1980, 31.

Kędzierska, Anna. „Badania użytkowe prowadzone w KGD”, Nasza Praca, nr 2, 1980, 86-87.

„Kierunki działania Ligi Kobiet Polskich w 1984 roku”, Nasza Praca, nr 2, 1984, 4-7.

Komar, Wanda. „Szkoły wychowania obywatelskiego w LK. Cele, zadania, program, perspektywy", Nasza Praca, nr 5, 1980, 35-38.

Krawczyk, Maria. „Portret Ojca”, Nasza Praca, nr 1, 1980, 69-78.

„Kronika wydarzeń”, Nasza Praca, nr 1, 1980, 91.

Kurzynowski, Adam. „Na urlop czy do pracy?”, Nasza Praca, nr 9, 1981, 22-27.

Laskowska, Maria. „Delegacja kobiet syryjskich w Polsce”, Nasza Praca, nr 1, 1980, 87-90.

Laskowska, Maria. „Książki dla rodziny”, Nasza Praca, nr 3, 1980, 36-39.

„Liga Kobiet domaga się...”, Nasza Praca, nr 6, 1981, 22-25.

Makowska, Agnieszka. „Poradnictwo społeczne i rodzinne LK”, Nasza Praca, nr 3, 1980, 52-57.

Markowska, Danuta. „O wychowaniu dla przyszłości”, Nasza Praca, nr 3, 1980, 64-71. 
„Materiały i dokumenty. Plenum Zarządu Głównego Ligi Kobiet”, Nasza Praca, nr 10, 1981, 1.

Mroczek-Szymańska, Melania. „Kobiety polskie w zwycięstwie nad faszyzmem i w walce o pokój”, Nasza Praca, nr 4, 1980, 15-26.

Nasza Praca, nr 1, 1980, 2.

Nasza Praca, nr 7, 1981.

"Od Redakcji”, Nasza Praca, nr 1, 1981.

Okoń, Halina. „Razem czy osobno”, Nasza Praca, nr 2-3, 1981, 60-62. „Plenum Krajowej Rady Kobiet Polskich przy Ogólnopolskim Komitecie FJN", Nasza Praca, nr 3, 1980, 5-7.

Regent-Lechowicz, Maria. „Wychowanie dla pokoju”, Nasza Praca, $\mathrm{nr}$ 4, 1980, 7-14.

Sławecka, Janina. „Podstawowe zagadnienia prawa spadkowego”, Nasza Praca, nr 1, 1980, 51-56.

„Socjalistyczne przemiany $z$ naszym udziałem. Referat przewodniczacej KRKP Eugenii Kempary", Nasza Praca, nr 2-3, 1981, 4-21.

Stojanowska, Wanda. „Pochodzenie dziecka. Cz. I. Sądowne ustalenie ojcostwa", Nasza Praca, nr 4, 1980, 58-66.

Szwarc, Halina. „5 lat działalności Uniwersytetu III Wieku”, Nasza Praca, nr 5, 1980, 66-70.

„Uchwała ZG LK w sprawie dalszego rozwijania działalności na rzecz pomocy rodzinie", Nasza Praca, nr 1, 1980, 25-27.

„Uchwała ZG LK w sprawie kampanii sprawozdawczo-wyborczej w kołach LK, ORW i KRM", Nasza Praca, nr 1, 1980, 28-29.

Wieczorek, Janusz. „Podziękowanie dla Ligi Kobiet”, Nasza Praca, nr 1, 1980, 3-4.

„Wizyta delegacji radzieckiej”, Nasza Praca, 1981, nr 8, 43-44.

"Zachęcamy do dyskusji”, Nasza Praca, nr 2-3, 1981, 57-60.

Zalewska, Krystyna. „Sekcja Budownictwa LK”, Nasza Praca, nr 2, 1980, 89.

„Założenia programowe Ligi Kobiet”, Nasza Praca, nr 10, 1981, 16-19. „Zjazd przyspieszony - wiosna '82”, Nasza Praca, nr 6, 1981, 11-19.

\section{Opracowania}

Bauchrowicz-Tocka, Maria. „Działalność Ligi Kobiet Polskich w okręgach katowickim i krakowskim w świetle publikacji "Naszej Pracy“ (1982-1989)", w: Małgorzata Dajnowicz, Adam Miodowski (red.), Ruchy kobiece na ziemiach polskich $w$ XIX $i$ XX wieku. Stan ba- 
dań $i$ perspektywy, (Białystok: Wydawnictwo Uniwersytetu w Białymstoku, 2020), 321-340.

Bauchrowicz-Tocka, Maria. „Ewolucja celów Ligi Kobiet w latach 1945-1989 w świetle jej statutów", Czasopismo Naukowe Instytutu Studiów Kobiecych, nr 1(8), 2020, 176-191.

Chłosta-Sikorska, Agnieszka. „Boginie PRL - nowe role kobiety w społeczeństwie socjalistycznym”, w: Bożena Popiołek, Agnieszka Chłosta-Sikorska, Marcin Gadocha (red.), Kobieta i mężczyzna jedna przestrzen - dwa światy, (Warszawa: Wydawnictwo DiG, 2015), 615-622.

Dajnowicz, Małgorzata. "Zwierciadło" - platforma polityczna Ligi Kobiet w okresie PRL (1957-1961, 1982-1989)", Rocznik Historii Prasy Polskiej, t. 20, z. 3(47), 2017, 67-90.

Dajnowicz, Małgorzata. „Działalność Społeczno-Obywatelskiej Ligi Kobiet w świetle "Naszej Pracy" (1947-1949)", w: Małgorzata Dajnowicz, Adam Miodowski (red.), Polityka i politycy $w$ prasie XIX i XX wieku, (Białystok: Wydawnictwo Humanica, 2016), 295-307.

Dajnowicz, Małgorzata. „Liga Kobiet w terenie. Kierunki działalności organizacji na przykładzie struktur białostockich w latach 1966-1981", Niepodległość i Pamięć, nr 2(62), 2018, 161-182.

Drozdowska, Agnieszka. „Działalność Ligi Kobiet w północno-wschodnich terenach Polski Ludowej w latach 1975-1989 w świetle "Naszej Pracy", Niepodległość i Pamięć, R. XXVI, nr 2(66), 2019, 184210.

Drozdowska, Agnieszka. „Liderki Ligi Kobiet Polskich wobec wyborów w latach 80. (w świetle "Naszej Pracy")", Czasopismo Naukowe Instytutu Studiów Kobiecych, nr 1(8), 2020, 194-209.

Drozdowska, Agnieszka. „O działalności Ligi Kobiet w okręgu białostockim (w świetle "Naszej Pracy")", w: Małgorzata Dajnowicz, Adam Miodowski (red.), Polityka i politycy $w$ prasie XX i XXI wieku. Polityka w prasie kobiecej (Białystok: Wydawnictwo Uniwersytetu w Białymstoku, 2019), 185-204.

Marcinkiewicz-Kaczmarczyk, Anna. „Rola Ligi Kobiet w popularyzowaniu polityki władz "Polski Ludowej", w: Dorota Litwin-Lewandowska, Krzysztof Bałękowski (red.), „Polska Ludowa” 1944-1989 - wybrane problemy historii politycznej i spolecznej, (Lublin: Wydawnictwo Naukowe Tygiel, 2016), 283-301.

Miodowski, Adam. „Działalność zagranicznych ruchów kobiecych w świetle publikacji "Naszej Pracy" - organu prasowego Społecz- 
no-Obywatelskiej Ligi Kobiet (1947-1949)", Czasopismo Naukowe Instytutu Studiów Kobiecych, nr 1(8), 2020, 140-157.

Miodowski, Adam. „Rozwój dolnośląskich i zachodniopomorskich struktur Społeczno-Obywatelskiej Ligi Kobiet w latach 19471949 w świetle publikacji "Naszej Pracy"”, w: Małgorzata Dajnowicz, Adam Miodowski (red.), Polityka i politycy $w$ prasie XX i XXI wieku. Polityka w prasie kobiecej, (Białystok: Wydawnictwo Uniwersytetu w Białymstoku, 2019), 167-183.

Sekuła-Kwaśniewicz, Halina. „Meandry ruchu kobiecego w czasach PRL", Annales Universitatis Pedagogicae Cracoviensis. Studia Politologica, nr X, 2013, 59-76.

Świętochowska, Emilia. „Sytuacja społeczno-zawodowa kobiet w ostatniej dekadzie PRL na przykładzie województwa białostockiego", w: Ewa Chabros, Agnieszka Klarman (red.), Kobiety na zakręcie 1933-1989, (Wrocław: IPN, 2014), 293-304.

\section{Zasoby internetowe}

Nowak, Barbara. Serving Women and the State: The League of Women in Communist Poland, Dissertation, (The Ohio State University, 2004), 248 [online] [dostęp: 9.04.2021]. Dostępny w World Wide Web <https://etd.ohiolink.edu/apexprod/rws_etd/send_ file $/$ send?accession=osu $1091553624 \&$ disposition=inline $>$. 